Economics Development Analysis Journal 6(3)(2017)

\title{
The Implementation of Law No 6 Year 2014 in The Village of Tempel Demak Regency
}

\author{
Nur Faizah ${ }^{凶}$
}

Economics Development Department, Economics Faculty, Universitas Negeri Semarang

\section{Info Artikel}

Article History:

Received April 2017

Accepted Juny 2017

Published Agust 2017

Keywords:

Implementation, Act 6 of

2014 on the village, Rural

Development,

Government of Village

\begin{abstract}
The purpose of this study was to determine and describe how the implementation of Law No. 6 of 2014 on the village as well as to identify barriers in the village of Tempel. Analysis of data using analytical methods Miles and Huberman. The theory used is the model of George C. Edward III implementation. The survey results revealed that the implementation of Law No. 6 of 2014 About Village Tempel seen from the aspect of communication, has done good communication between the implementers (village government) with policy targets (Rural Community), from the aspect of resource that government resources Desa Paste not support, from the aspect of attitude executor, implementor claimed responsibility and commitment to the implementation of the policy of Act No. 6 of 2014 About the village, and the bureaucratic structure has not been eligible effectively. Obstacles faced by the village government Tempel is on aspects of communication there has been no followup of village representatives who had attended socialization, briefing and training to the other village. In the aspect of the attitude of the implementing namely the lack of response from the public who think the policy is only a mere routine policy, the necessary attitude of high responsibility of the implementor. There are still bureaucratic structure of government resources and Paste village that has not been fully in accordance with Law No. 6 of 2014 About the Village.
\end{abstract}

\begin{tabular}{lr}
\hline${ }_{\text {Corresponding Author: }}$ & ISSN 2252-6765 \\
Journal's Room, L Building, FE UNNES Sekaran Gunungpati & \\
Semarang 50229, Indonesia & \\
E-mail: aizraffa@yahoo.com &
\end{tabular}




\section{INTRODUCTION}

Poverty is one of the main problems that the government prioritizes in formulating development strategies. These strategies belong government's triple track strategy, which are poverty alleviation, job creation, and economic growth. In accordance with the Monthly SocioEconomic Report published by Central Bureau of Statistics (BPS) in December 2014, there are still many poor Indonesians. It can be seen in the picture below.

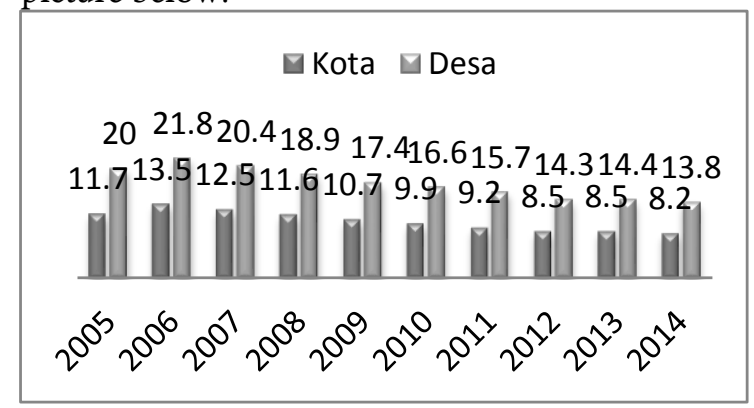

Figure 1. The Percentage Figure of the Living Population Below the Rural and Urban Poverty Line in Indonesia Year 2005-2014 Source: BPS, processed data

Based on the above picture, it can be seen that the percentage of poor people in Indonesia tends to decrease, but the percentage of poor people is still high in rural areas compared to urban areas. In addition, the current development that has been focused on urban areas has increased the gap between rural and urban areas. The impact can be seen on the increasing index of gini. Meanwhile, efforts to balance the economic condition to the countryside are realized by the government in 2014 regarding a law that specifically regulates the village, namely Law No. 6 of 2014 on the Village. The existence of those Law is expected to have real and responsible village autonomy implementation and able to strengthen the village community both from the side of government, accountability, and governance.

After the ratification of Law No. 6 of 2014 or better known as the Village Law, followed by the enactment of Government Regulation No. 43 of 2014 on guidelines on the implementation of Village Law and Government Regulation No. 60 of 2014 on village fund management mechanisms originating from the State budget of revenues and expenditures (APBN), it is found that there is a shift in the paradigm and budget management mechanism in the village. So the village government needs to take strategic and tactical steps regarding preparing the rules of support, adjusting the village mid-term development plans, preparing the Village budget of revenues and expenditures (APBDes) and its realization, developing and strengthening the Village-run enterprises (Bumdes), and preparing community assistance. To some extent, this change increases the difficulty in our understanding the regional rural development and thus brings about challenges for the making of feasible regional rural development policies and strategic planning (Li, et al., 2015)

The State progress basis is determined by the progress of Village. The existence of Law No. 6 of 2014 on the Village contains various changes. One of which is the Village Fund program estimated at $\mathrm{Rp} 1.4$ billion. The details of the village funds in APBN-P 2015 have been published by the government as reported from the official website of the Directorate General of Fiscal Balance of the Ministry of Finance (DPJK Kemenkeu) of 33 receiving provinces and 5 (five) of them pocketed the most budget. The province, among others, Central Java of Rp. 2.23 trillion, East Java Rp. 2.21 trillion, Aceh for Rp. 1.71 trillion, West Java of Rp. 1.59 trillion, and North Sumatra of Rp. 1.46 trillion.

In Central Java there are 7809 recipient villages of Village Funds (DD) spread over 29 regencies, the total DD in 2015 in Central Java reached $\mathrm{Rp} 5,002,426,341,000$. while the first phase of DD that can be disbursed was located in 15 regencies consisting of 4,009 villages with a total of $\mathrm{Rp} 1,535,607,800$. Meanwhile. for Demak District, in Fiscal Year 2015 was allocated Rp.73,852,473,000, - and in Budget Year 2016, it got an allocation of Rp.165,814,611,000, -. From data taken from the socialization of Wedung Subdistrict in 2015, it got DD of $6,051,339,257$ which would be distributed to 20 villages. Further, each village will get $\mathrm{Rp} 302$ million in average. 
Based on the reality mentioned above, there is no excuse for any village in Wedung Subdistrict to complain in terms of village development. Similarly, especially the Village of Tempel in Wedung Subdistrict which becomes the setting of this study because as DD that has been received is allocated well, it will be very helpful for the implementation of the village government programs in term of village development maximally.

One of the villages that have implemented Law No. 6 of 2014 is Tempel Village in Wedung Subdistrict, Demak Regency. The enactment of Law No. 6 of 2014 on Village in Tempel Village results in changes to the institutional structure and performance of the village government of Tempel in the implementation of the development of villages. In addition, it also affects the changes in governance implementation of village administration in the village. In the implementation of its duties, the Tempel village government is guided by Law no. 6 Year 2014. Besides, the existence of DD sourced from the APBN for this village is a quite big. In all its essence, the growth strategy states that smart growth supports sustainable development, which is achieved by promoting research, innovation, and knowledge in order to attain regional economic growth (Naldi, et al., 2015)

In relation to the phenomenon described above, the researcher was encouraged to study, examine, investigate and discuss the implementation of Law No. 6 of 2014 on the Village compiled in the form of a final project entitled: "The Implementation of Law No. 6 of 2014 on Village in Tempel Village, Wedung Subdistrict, Demak Regency.

\section{RESEARCH METHOD}

The approach of research used in this study was descriptive qualitative, that is the research approach where the collected data are in the form of words and not numbers. In this case, the data were obtained from interviews, field notes, notes or memos and other documentation. Moreover, this qualitative descriptive research approach details the implementation of Law No.
6 of 2014 on the Village in the village of Tempel, Wedung Subdistrict, Demak Regency. Further, this study described the implementation of Law No. 6 of 2014 and the constraints faced in its implementation. For more, the subjects of this study were the people who served in the government of Tempel Village. The determination of the subjects or informants in this study was by using purposive method.

Focus of the Study, The focus of this study was the Public Policy Implementation Model proposed by Edward III which has four aspects that play an important role in successful implementation. The four aspects are communication, resources, disposition and bureaucratic structure. By using the Edward III model, the Four aspects which become important criteria in the implementation of a policy are defined as follows; a) Communication covers the communication between the policy operative personnel (village government apparatus) with the target group (village community), b) Resources include human resources and financial resources available or provided for the implementation of the Law No. 6 of 2014, c) The Implementing Stance is a characteristic attached to the policy implementers (village government officials), including honesty, commitment and democratic attitude, d) Bureaucratic Structure is the organizational structure of policy implementers.

This study was conducted in Tempel Village, Wedung Subdistrict, Demak Regency. The selection of research sites was based on the consideration of the substance compliance of the problems in this study and of data entry for people, programs, structures, and interactions in accordance with the needs of the study.

Types and Data SourceE, Primary data is data obtained from the subjects (informants). Meanwhile, the data source in study was the subjects from which the data can be obtained. Therefore, the researcher obtained data sources from: Informants and Field Notes, Secondary data come from supporting documents in study. The secondary data source in this study came from any documents obtained by researcher from the place of research, namely the Office of 
Tempel Village and other data related to problem faced by researcher to be reference material during research process.

Method of collecting data, To obtain necessary data and information for this qualitative research, the researcher involved informants. The informants of this study were the people involved in the implementation of Law No. 6 of 2014 on village in the Village of Tempel Wedung Subdistrict, Demak, namely: Village Head representing the village, as well as village staffs. Their data were collected via interview And documentation,

Data Validity Inspection Technique, ihe data triangulation method used in this study was micro-level nature method, such as how to use multiple data collection methods and data analysis together in a research, including using informants as a validity test tool and research analyst. The assumption is that the information obtained by the researcher through observation will be more accurate if it is also supported by interviews or using documentation materials to correct the validity of information that has been obtained with both methods. Similarly, the results of data analysis conducted by the researcher will be more accurate when the validity is tested through cross-test with other informants, including the research informants.

Data analysis method, data analysis is the process of searching and systemically compiling data obtained from interviews, field notes and documentation by organizing data into categories, describing to units, synthesizing, compiling into patterns, choosing which ones are important and that will be studied and make conclusions to make it easily understood by one or others (Sugiyono, 2013: 334).

This study used qualitative data analysis from Miles and Huberman (Sugiyono 2009: 246), which consists of four stages: Data collection, Data Reduction, Data Presentation and Conclusion Drawing.

\section{RESULTS AND DISCUSSION}

The Overview of the Implementation of Law No 6 of 2014 on Village in Tempel Village, the implementation process of the Law No. 6 of 2014 on Village in Tempel Village, namely:

First, the village government prepares a plan covering basic village information as well as the explanation of needs referring to the purpose of village development in accordance with the village law article 80 .

Second, implement Village Community Consultations on Development Planning (MUSRENBANG DESA) involving the village government, Village Consultative Body (BPD) and community groups. MUSRENBANG DESA discusses the determination level of needs assessment of the community and sets priorities, programs and activities to be undertaken.

Third, the determination of the plan is realized by creating Village Medium-term Development Plans (RPJMDES) and Plans for Village-level Development (RKPDES) set by Village Regulation (PERDES) with the provision of one village only one plan. In this section, the plan referred to is the Village Government Budget (APBDESA) guideline that is consistent with the input in the regency plan.

After establishing the development plan, the next step is to determine APBDESA, the APBDESA contains consolidation of revenues and expenditures, stipulated in PERDES. Its allocation must be in accordance with the development needs and priorities of the Regency. After APDESA has been established, the next stage is the implementation of development. This stage is required to involve the whole community and or community institutions, carried out by self-managed, and the community is entitled to obtain information, monitor and report.

The next stage is accountability. At this stage, the village government must submit a report in the village development consultation.

The final stage results that the community and the village government mutually maintain and utilize village funds in a good and transparent so that the village law order can be achieved. For more, the details can be seen in the following picture: 


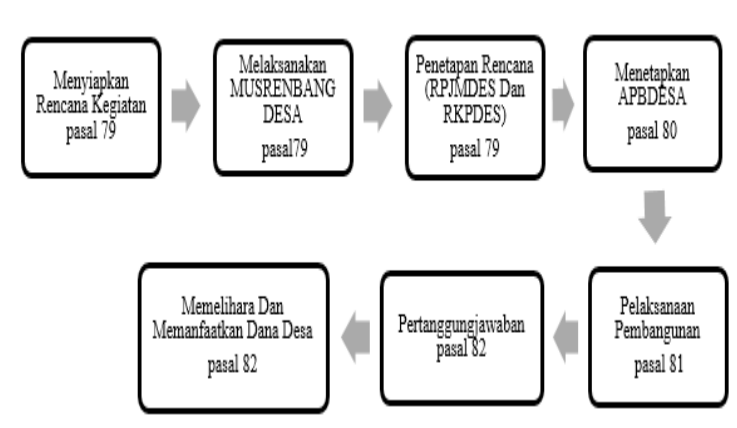

Figure 2. The Implementation Process of Village Law No. 6 of 2014 on village article 78-82 in Tempel Village in 2015.

As the follow up of the implementation process of Law No. 6 of 2014 on village, village governments are required to implement village development plans in accordance with mediumand long-term development plans. Based on the results of interviews with informants, it was known that that the Tempel village government has made some program activities, including: First, village north road improvement program. This program is based on the condition of the village's very bad north road. In fact, the north road of the village is the main access for the people of Tempel village.

Second, rice field road improvement program. This program exists because the majority of villagers of Tempel Village work as farmers, so their main activity is in rice field. The clay textured soil conditions make it difficult to access road to rice field. It can only be accessed by foot. Therefore, the village government makes an effort to improve rice field roads to make it easier for villagers to grow crops.

Third, the program of repairing the village head office. This is done because the condition of the old village head office was in a bad state, so the village government is trying to improve the village head office in order to serve the community comfortably and easily.

Fourth, road improvement program in front of the village hall office. This is because the road conditions are still rocky so that the community is difficult to access to the village head office. Furthermore, the village government to repair the road by way of concrete the road in front of the village office.
Fifth, culverts building program. This is aimed at reducing the risk of floods that hit the village of Tempel.

In relation to the implementation of village development programs to implement Law No. 6 of 2014 on village, each village is granted a village budget fund sourced from APBN. The obtained village funds budget is used for the activities of Government Apparatus and Village Government Operations in Tempel Village. There are several things that need to be described and analyzed by the researcher regarding the use of village funds and their implementation.

In 2015, Tempel Village got village funds of Rp. 301,100,000,-. For the management, village funds is regulated in Demak Regent's Regulation No. 23 of 2015 with the provisions of the activities of Government Apparatus and Operations Village. The data refer to the SPJ or accountability of the use of the Village Funds.

According to the List of Activity Plans (DRK) of Tempel Village Village Funds Purchase Fiscal Year 2015, the funds sourced from APBN was the first channeling of funds. The funds were channeled into the Village Cash Account through 3 phases with details, the first phase of $40 \%$, the second phase of $40 \%$, andthe third phase of $20 \%$.

The priority description of the use of village funds as the source of village development activities in Tempel Village can be seen in Table 1 below:

Table 1. Priority Table of Use of Village Funds in Tempel Village 2015

\begin{tabular}{|c|c|c|}
\hline PHASES & ACTIVITY PROGRAMS & $\begin{array}{l}\text { REALIZA } \\
\text { TION (\%) }\end{array}$ \\
\hline $\mathrm{I}$ & $\begin{array}{l}\text { - Batching the main road of } \\
\text { the village along } 1500 \mathrm{~m} \\
\text { - Repair of paddy road } \\
\text {-Repair of the village tomb }\end{array}$ & $\begin{array}{l}100 \\
100 \\
100\end{array}$ \\
\hline II & $\begin{array}{l}\text { - Repair of village head } \\
\text { building } \\
\text {-Front road improvement of } \\
\text { the village head office }\end{array}$ & $\begin{array}{l}70 \\
90\end{array}$ \\
\hline III & - Making culvers & 0 \\
\hline
\end{tabular}

Processed. 
The above table shows that the priority of the use of village funds for village development in Tempel Village was well realized, namely with the percentage of nearly $100 \%$. This is in accordance with the observation in the field that the whole process of village development almost ran well and the physical form of village development could be felt by the community.

Based on the overall research result related to Implementation of Law No. 6 Year 2014 on Village, it can be concluded that Implementation of Law No. 6 Year 2014 on Village in Tempel Village is quite good, but in accordance with the observation in the field, there are some provisions of Law No. 6 Year 2014 about the Village that have not been implemented by the government of Tempel Village, among others, the lack of community economic development programs such as the establishment of Villageown enterprises (BUM Desa), Village Market, Village Rice barn, breeding of food crops, strengthening the capital BUM Desa, as well as the absence of participation from women in governance as arranged in Law No.6 of 2014 on Village article 82.

Implementation of Law No. 6 of 2014 on Villages in Tempel Village, to investigate the implementation of Law No. 6 of 2014 on Village in Tempel Village based on the aforementioned four aspects, interviews were conducted with the informants. The interviews were conducted using guidelines / interview guides that had been prepared in advance. Their data were analyzed by qualitative analysis technique of interactive model. The results of data analysis are presented descriptively-qualitative as follows:

Communication, the Tempel village government explained that so far it has received socialization related to the implementation of the policy of Law No. 6 of 2014 on Village through workshops, technical guidance and learning and coordination meeting. The village administration has understood the material presented in the socialization, covering the concept of Law No. 6 of 2014 on Village, terms and conditions of disbursement of village funds, village fund mechanisms, monitoring and evaluation, authority and reporting of Law No. 6 of 2014 on
Villages. All Tempel village officials know that there are representatives from the Tempel village government who participated in socialization, briefing and training in order to prepare themselves for the implementation of the policy of Law No. 6 of 2014 on Village by local government, in this case is the regency and provincial government to the village government in order to streamline the implementation of the policy of law number 6 of 2014 on the village. Based on the results of interviews, the way of delivering information or the transmission of policy implementation of Law No. 6 of 2014 on the Village realized in socialization was done through workshops, technical guidance and learning, and coordination meetings.

Law No. 6 of 2014 on Village has stipulated in Article 26 paragraph 4 point $p$ that the Village Head is obliged to provide information to the village community. Information on the Village Government can also be requested and obtained by the village community, and can oversee all activities undertaken by the Village Government (Pemdes). One of which is the Development of Villages which are listed in Law No. 6 year 2014 Article 68 paragraph 1 point a. Meanwhile, communication between village head is not only done in one way, but also the villagers can give their aspirations, suggestions and oral or written opinions responsibly about activities in the village in accordance with the Law No. 6 year 2014 Article 68 paragraph 1 point c. In addition to that, Village Law also regulates the Village Consultation as what is stated in article 54 that Village Consultation is conducted at least 1 meeting in 1 year to discuss things in the implementation of Village Government.

Resources, in the aspect of resource, 4 (Four) informants had the same argument that the availability of human resources in implementing Law No. 6 of 2014 on village in the head office of Tempel Village is still inadequate. Due to the shortage of personnel, despite having sufficient formal education, the skill / ability of the human resources in the field of work is not adequate. The same thing also goes to supporting facilities and infrastructure. 
In accordance with Law No. 6 Year 2014 on Village Article 1, village development resources are conducted to make village community become independent and prosperous. They are realized by increasing knowledge, attitude, skills, behavior, ability, awareness, and utilizing other resources through policies, programs , activities, and assistance in accordance with the essence of the problems and priority needs of villagers. The existence of the resources factor in the implementation of the policy of Law No. 6 of 2014 on the Village plays a very important role in the success of policy implementation. Without sufficient resources, what is planned will not be the same as what is finally applied.

According to George Edward III: resources can be a critical factor in implementing public policy. Important resources include staff with sufficient numbers and their skills to perform their duties and information, the necessary authorities and facilities to translate the proposal to the paper into public service delivery. Due to the unavailability of insufficient resources, it will create obstacles to policy implementation.

Operative Personnel Attitude, in the aspect of the operative personnel attitude, the 4 (four) informants had the same opinion that the attitude shown by the program implementers (village government), such as good commitment, honesty and passionate in community service is adequate.

Operative personnel Attitude is defined as the tendency, desire or agreement of the implementers to implement the policy. If the policy implementation is to succeed effectively and efficiently, the implementers not only know what to do and have the ability to carry out the policy, but also the will to implement the policy. This Operative personnel Attitude is a characteristic that is firmly attached to the policy Operative personnel. Important characters which are supposed to be owned by policy Operative personnel are honesty, commitment, democratic, willingness, desire, and the tendency of policy actors to implement seriously. The great operative personnel attitude affects the success rate of policy implementation.

In line with the above theory, the results of this study showed that the village head and employees of Tempel Village, already have a high commitment, the nature of honesty and high dedication in implementing Law No. 6 of 2014 on Village, as well as have a democratic nature in providing services to the community. From the results of the description, the researcher assessed the good cooperation between village government and community due to the awareness of both parties to make better village development.

Bureaucratic Structure, in the aspect of bureaucratic structure, the 4 (four) informants had the same argument that the organizational structure of Tempel Village Government has not been eligible to implement the policy of Law Number 6 Year 2014 on the Village effectively. Following are the charts of the structure of the village government organization between the Act No. 6 of 2014 with the village government organizational structure in Tempel Village that illustrates the differences.

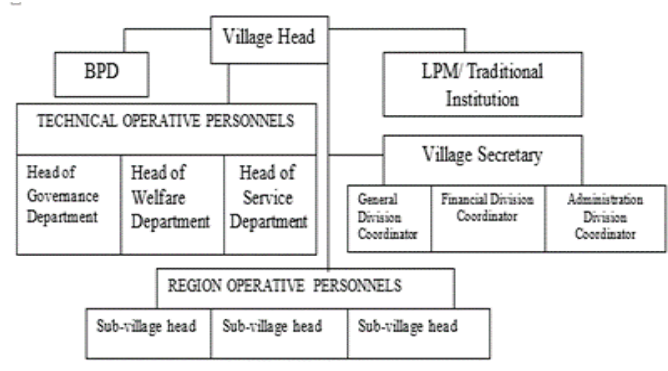

The Chart of Organizational Structure based on Law Number 6 Year 2014

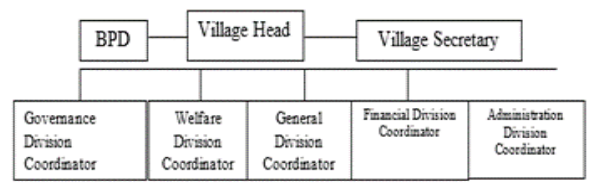

Picture 3. The Chart of Tempel Village Organizational Structure in 2015

According to the above two charts, apparently Tempel Village organizational structure has not been matched with what is stated in Law Number 6 Year 2014. Therefore, Tempel Village government needs to do revision 
on the organizational structure based on what is regulated in Laws.

Furthermore, based on the above description, it can be concluded that Tempel villaged has not effectively fulfilled the criteria of bureaucratic structure in relation to Law Number 6 Year 2014 on Village. Such matter is seen from: first, the completeness of bureaucratic structure which has not yet been adjusted to Demak Regional Regulation number 6 Year 2007 on the Guidelines in Arranging Organization and Working Procedures of Village Government with Law Number 6 Year 2014 on Village. Second, the operative personnel organizational structure, Operational Procedure Standards (SOP), procedure mechanisms of village development, as well as time allotment of program completion have not been suitable with the guidelines.

Constraints Faced by Village Government in Implementing Law Number 6 Year 2014 on Village in Tempel Village : Communication, constraint found in this aspect was related to the existing socialization to the village community related to Law Number 6 Year 2014 on Village which was the opposite of villagers low level of education, namely primary education. It affected toward community low understanding on the Law. Being socialized. This phenomenon would result on the complication of involving community to participate on the implementation of Law Number 6 Year 2014 on Village as well as activities supervision. Other constraints in the aspect of communication also occurred between village head and village government members regarding different perception on the policy of the occupied village government members placement according to Law Number 6 Year 2014 on Village. In this case, the village secretary suggested that any villages which have implemented Law Number 6 Year 2014 on Village are supposed to recruit new and prepared members to improve the quality of village government members.

Resources, constraint on this aspect deals with the low level of education of the operative personnel of Law Number 6 Year 2014 on Village, for the understanding of Law Number 6 Year 2014 on Village was varied and not thorough enough. The same thing also went to the targets of Law Number 6 Year 2014 on Village, namely community. Some causes of these problems were the insufficient village income which resulted on the lack of financial support on the policy implementation and limited good quality of human resources.

Operative personnel Attitude, constraint found on this aspect was the low response of the villagers in facing Law Number 6 year 2014. They thought that its policy only dealt with the distribution of the high number of village funds without seeing its great responsibility. This constraint could obstruct the implementation process of Law Number 6 year 2014 on Village in Tempel Village. Provide differentiated and high value-added products to local producers in the rural areas while the willingness of the purchasing these kind of traditional products are high (Dogan \& Ummuhan, 2015)

Bureaucratic Structure, constraint found on aspect was the rapid change of Operational Technique Procedure (PTO) so that the Executor Team of the Activities (TPK) found a difficulty in buying any stocks in suppliers. It caused delay on any building activity. Moreover, there was no tasks distribution and lack of coordination in executor team of Law Number 6 year 2014 on Village. This constraint could obstruct the implementation process of Law Number 6 year 2014 on Village in Tempel Village.

\section{CONCLUSION}

Based on the above description regarding the implementation of the policy of Law Number 6 Year 2014 on Village in Tempel Village, the following conclusions are made The implementation of Law Number 6 Year 2014 on Village in Tempel Village is seen from four aspects. First, the communication aspect has been done in a good way between policy operative personnel (village government) with policy targets (Villagers). Second, in resources aspect, the Government of Tempel Village apparently has lacked of support. Third, operative personnel attitude aspect shows that the operative personnel expresses their responsibility and commitment to implement the 
policy of Law Number 6 Year 2014 on Village. Fourth, the bureaucratic structure aspect has not yet qualified effectively.

Constraints faced by Tempel Village Government in the implementation of Law no. 6 Year 2014 on Villages are no follow-up from village representatives who have participated in socialization, training and workshop with other village apparatus. Meanwhile, the aspect of the executive attitude shows that villagers admit this policy as a merely routine policy. From this phenomenon, there is a need to take a high degree of responsibility from the operative personnel. Additionally, there are some resources and bureaucratic structures of the Tempel Village Government which are not yet complete in accordance with Law Number 6 Year 2014 on Village.

Based on the conclusions, some suggestions are given in the followings : Tempel village government is advised to improve all important aspects of both communication, resources, operative personnel attitude, and bureaucratic structure within the framework of the implementation of Law No. 6 of 2014 on Village in Tempel Village the better direction. The government is also suggested to be more selective in choosing and setting development programs, so future development programs are not only focused on the sector of facilities and infrastructure, but also in terms of development of local economic potential, community is encouraged to further improve their knowledge of Law Number 6 Year 2014 on the Village, so that they can play an active role in Musrembangdes, development and supervise any development in Tempel Village.

\section{REFERENCES}

Badan Pusat Statistik. 2015. Laporan Bulanan Data Sosial Ekonomi, Edisi 55. Jakarta.

Cahyadi, Eddy. 2016. Implementasi progam community development bidang pendidikan dalam upaya peningkatan kualitas SDM dan pemecahan masalah kemiskinan. EDAJ 5 (2)(2016)
Nugroho, Riant. 2004. Kebijakan Publik Formulasi, Implementasi dan Evaluasi.Jakarta:PT.Elek Media Komputindo.

Subarsono, AG. 2013. Analisis Kebijakan Publik (Konsep, Teori dan Aplikasi).Yogyakarta: Pustaka Pelajar

Sugiyono. 2009. Metode Penelitian Pendidikan : Pendekatan Kuatitatif, Kualitatif

dan R \& D. Bandung : Alfabeta. 2009. Metode Penelitian Kuantitatif Kulitatif Dan R\&D. Bandung: Alfabeta

Widodo, Joko. 2011. Analisa Kebijakan Publik. Malang: Bayu Media Publishing

Winarno, Budi. 2005. Kebijakan Publik Teori dan Proses. PT. BUku Kita, Jakarta.

Demak Regional Regulation Number 6 Year 2007 on Guidelines in Arranging Organization and Working Procedures of Village Government. (Peraturan Daerah Kabupaten Demak No 6 tahun 2007 tentang Pedoman Penyusunan Organisasi dan Tata kerja Pemerintah Desa)

Dogan, Bilge \& Ummuhan Gokovali. 2012. Geographical Indications: The Aspects of Rural Development and Marketing Through the Traditional Products. Social and Behavioral Sciences, Volume 62, Pages 761-765

Government Regulation Number 43 Year 2014 on The Implementation of Village Laws, revised by Government Regulation Number 47 Year 2015 on The Implementation of Village Laws. (Peraturan Pemerintah Nomor 43 Tahun 2014 Tentang Pelaksanaan Undang-Undang Desa, direvisi Peraturan Pemerintah Nomor 47 Tahun 2015 Tentang Pelaksanaan UndangUndang Desa)

Government Regulation Number 60 Year 2014 on Village Funds, $1^{\text {st }}$ Revision of Government Regulation Number 22 Year 2015 on Village Funds, $2^{\text {nd }}$ Revision of Government Regulation Number 8 Year 2016 on Village Funds, (Peraturan Pemerintah Nomor 60 Tahun 2014 Tentang Dana Desa, Revisi I Peraturan Pemerintah No 22 Tahun 2015 Tentang Dana Desa, Revisi II Peraturan Pemerintah No 8 Tahun 2016 Tentang Dana Desa,)

Law of the Republic of Indonesia Number 6 Year 2014 on Village. (Undang-Undang Republik Indonesia Nomor 6 Tahun 2014 Tentang Desa.)

Li, Yurui, et al,. 2015. Spatio-temporal pattern of China's rural development: A rurality index perspective. Journal of Rural Studies, Volume 38, Pages 12-26 
Minister of Home Affairs Regulation Number 113 on Village Funds Management. (Permendagri No 113 Tentang Pengelolaan Keuangan Desa)

Minister of Home Affairs Regulation Number Number 114 on Guidelines of Village Development (Permendagri No 114 Tentang Pedoman Pembangunan Desa)

Naldi, Lucia, et al,. 2015. What is smart rural development?. Journal of Rural Studies, Volume 40, Pages 90-101

Plans for Village-level Development (RKP-Des) Fiscal Year 2015 Tempel Village, Wedung Subdistrict, Demak Regency, Year 2015 (Rencana Kegiatan Pembangunan Desa (RKPDes) Tahun Anggaran 2015 Desa Tempel Kecamatan Wedung Kabupaten Demak Tahun 2015)

The Report of Tempel Village Government, Wedung Subdistrict, Demak Regency (Laporan Pemerintahan Desa Tempel Kecamatan Wedung Kabupaten Demak Tahun 2015),

Tempel Village Regulation Number 6 Year 2015 on Public Accountability Report on Budget Implementation of the Realization of APBDes Development (Peraturan Desa Tempel Nomor 6 tahun 2015 tentang Laporan Pertanggungjawaban Realisasi Pembangunan APBDes) 